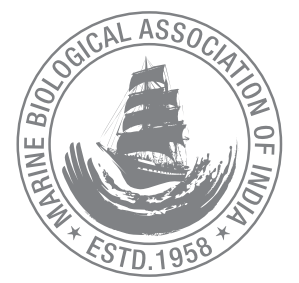

\title{
Intestinal bacterial diversity of Charybdis (Charybdis) feriata (Linnaeus, 1758) from Kerala coast
}

\author{
Anu Mathew*1 and Imelda Joseph \\ ICAR - Central Marine Fisheries Research Institute, Ernakulam North P.O.,Kochi - 682 018, Kerala, India. \\ 'Mangalore University, Mangalagangotri-574 199, Karnataka, India. \\ *Correspondence e-mail: anuchalilm@gmail.com
}

Received: 10 Dec 2019 Accepted: 25 Dec 2019 Published: 30 Dec 2019

Original Article

\begin{abstract}
Considering the increasing demand and scope for aquaculture of crucifix crab Charybdis (Charybdis) feriata (Linnaeus, 1758) an attempt was made to study its intestinal bacterial diversity. The intestinal bacterial diversity of $C$. feriata from three different sites along the Kerala coast was examined using conventional biochemical techniques as well as by $16 \mathrm{~S}$ rRNA gene sequencing. The total bacterial count in the intestine of $C$. feriata ranged from $1.5 \times 10^{6}$ to $3.2 \times 10^{6} \mathrm{cfu} . \mathrm{g}-1$ (colony forming unit per $\mathrm{g}$ tissue). The predominant isolates were genera Pseudomonas, Bacillus, Microbacterium and Dermacoccus. Among these two isolates one having protease and other with amylase and cellulase activity were selected for molecular characterization by 165 rRNA gene sequencing. They were identified as Microbacterium oxydans KU937308 and Dermacoccus abyssi KU937309 respectively. Since protease, amylase and cellulase are important in the areas of food processing, detergent, textile, pharmaceutical products, dairy, beverages and feed industries the isolates can be further screened for such applications. Dermacoccus abyssi has been found to be useful in biocleaning of industrial dye baths and Microbacterium oxydans in reutilization of brownseaweed waste.
\end{abstract}

Keywords: Charybdis feriata, intestinal bacterial diversity, Microbacterium oxydans, Dermacoccus abyssi

\section{Introduction}

Crustacean fishery makes a noteworthy impact to the worldwide nutritional security and livelihoods of people residing in coastal areas (Bondad Reantaso et al., 2012). Among marine crustaceans, crabs occupy vast position in terms of export capacity and dietary value (Varadharajan and Soundarapandian, 2014). Exploration of intestinal bacterial range in crab forms a topic of interest due to its importance in isolating and identifying potential bacteria having high specificity for recalcitrant compounds. Due to its benthic habitat, crabs receive bacteria in the intestine from the aquatic environment through water and the food it consumes.

There are reports on intestinal bacterial diversity of marine crabs like Scylla serrata, S. tranquebarica, Portunus pelagicus, P. sanguinolentus, Charybdis helleri (Ravichandran and Kannupandi, 2005; Rameshkumar et al., 2009) and Eriocheir sinensis (Li et al., 2007). Kannathasan and Rajendran (2010) have reported Acinetobacter baumanii, Bacillus subtilus, Escherichia coli, Klebsiella pneumonia, Micrococcus luteus, Proteus mirabilis, Pseudomonas aeruginosa, Staphylococcus aureus, Salmonella typhi, and Vibro cholera from carapace, gills, hepatopancreas, gonad, muscle and alimentary canal of Charybdis natator. The intestinal bacterial diversity represents an atmosphere of the 
highest complexity and our understanding of this biochemical system and its interactions are constrained (Reiji et al., 2004; Gatesoupe, 2007). An understanding of the host intestinal bacterial floral interactions is significant for the improvement of farming conditions and to optimize the species growth in aquaculture (0xley et al., 2002). Intestinal microorganism also has specific role in nutrients digestion and offer the host with physiologically active substances, like enzymes, amino acids and vitamins (Sugita et al., 1997). Symbiotic bacteria in an animal's digestive tract often produce enzymes that could supplement for digestion of foods as well as synthesize compounds that are assimilated by the host (Saha et al., 2006). Screening microbes from commercially important marine crab species in opposition to aquatic pathogens has been reported as useful in developing autochthonous probiotics for the farming of those animals (Verschuere et al., 2000).

Charybdis feriata is an ecologically important portunid crab species, widely distributed in Pacific and Indian oceans. Rajendran et al. (2008) identified five bacterial species from different tissues of ice stored $C$. feriata. However, it remains incomplete without studying the bacterial flora in the fresh intestine of C. feriata. Such information will be useful to understand the immunity aspects of the animal, its nutritional requirement and also to ensure the safety for human consumption. In view of its application in aquaculture, a study was conducted to estimate the bacterial diversity in $C$. feriata and to screen out some bacteria having biotechnological applications.

\section{Material and methods}

\section{Collection of crab and preparation of inoculum}

Five numbers of $C$. feriata from each centre were collected from three locations along the Kerala coast. Sampling was done from Kollam-Neendakara harbour, Alappuzha-Thottapally harbour and Calicut-Beypore harbour. Samples were collected and transported live to the laboratory and the digestive tracts were removed, cleaned and cut into pieces. The pieces were transferred to sterile petri-plates and thoroughly flushed with chilled sterile saline $(\mathrm{pH} 7.4 ; 0.89 \% \mathrm{NaCl})$, and homogenized using normal saline (10:1; volume: weight). The homogenate thus obtained was used as inoculum for culture.

\section{Enumeration and characterization of bacterial isolates}

The numbers of cultivable bacterial cells present in crab intestine were estimated after isolation and growth on nutrient agar medium supplemented with $2 \%(\mathrm{w} / \mathrm{v})$ sodium chloride and incubated at $35 \pm 2^{\circ} \mathrm{C}$ for $48 \mathrm{~h}$. Morphological, biochemical and physiological tests were performed for characterization of the bacterial isolates up to genus level by following Bergey's Manual of Systematic Bacteriology (Holt et al., 1994). The regular tests followed were gram stain, motility, oxidase activity, catalase activity ( $3 \%$ hydrogen peroxide solution), oxidation/fermentation, nitrate reduction, sugar tests and pigment production. All bacterial isolates characterized up to genus level were analysed for enzymes like amylase, (Sanchez-Porro et al., 2003), protease, gelatinase and cellulase (Kasana et al., 2008). The presence of the enzymes was recorded as growth, or a clear zone around the colony with/without the addition of respective reagents after incubation at $30 \pm 2{ }^{\circ} \mathrm{C}$ for $24 \mathrm{~h}$. The isolates were also screened to study their tolerance to varying degrees of temperature, salinity and $\mathrm{pH}$. The tolerance to salinity was tested in a nutrient broth medium with different concentrations of sodium chloride (Nacl, 0, 5, 10, 15, 20, 25 and 30\% w/v) (Yeon et al., 2005). The temperature resistance of the isolates was studied on nutrient agar plates by growing them in a wide range of temperatures ranging from 4 to $60^{\circ} \mathrm{C}$. The $\mathrm{pH}$ tolerance was examined by growing the isolates in nutrient agar medium at different $\mathrm{pH}$ ranging from 4 to12.

\section{Molecular characterization of selected bacterial strains}

For sequencing and phylogenetic analysis, DNA was extracted from the selected culture using phenol chloroform extraction method (Sambrook and Russell, 2001). PCR amplification of the $16 \mathrm{~S}$ rRNA genes were carried out with the universal primers $27 F$ (5'- AGAGTTTGATCCTGGCTCAG-3') and 1492R (5'- GGTTAC CTTGTTACGACTT-3') (Lane et al., 1985). The purified amplicons were custom sequenced by using the sequencing facility of $\mathrm{M} / \mathrm{S}$ Sigenome, Kochi. The nearest taxa of the 16S rRNA gene sequence (1418-1542 bases) were identified by BLAST sequence similarity (https:// blast.ncbi.nlm.nih.gov/Blast.cgi). The CLUSTAL W software was used to align 16S rRNA gene sequences and Maximum Likelihood (ML) and neighbour - Joining methods with MEGA version 5 (Tamura et al., 2011) were used to construct the phylogenetic tree.

\section{Results}

\section{Total bacterial count}

The total bacterial load from the $C$. feriata intestine ranged between $1.5 \times 10^{6} \mathrm{cfu} . \mathrm{g}^{-1}$ and $3.2 \times 10^{6} \mathrm{cfu} . \mathrm{g}^{-1}$. The maximum count of $3.2 \times 10^{6} \mathrm{Cfu} . \mathrm{g}^{-1}$ was obtained in the sample from Kollam and minimum $1.5 \times 10^{6} \mathrm{cfu} . \mathrm{g}^{-1}$ from Calicut sample.

\section{Bacterial isolates from intestine}

A total of 6 bacterial strains were isolated from the intestine of 


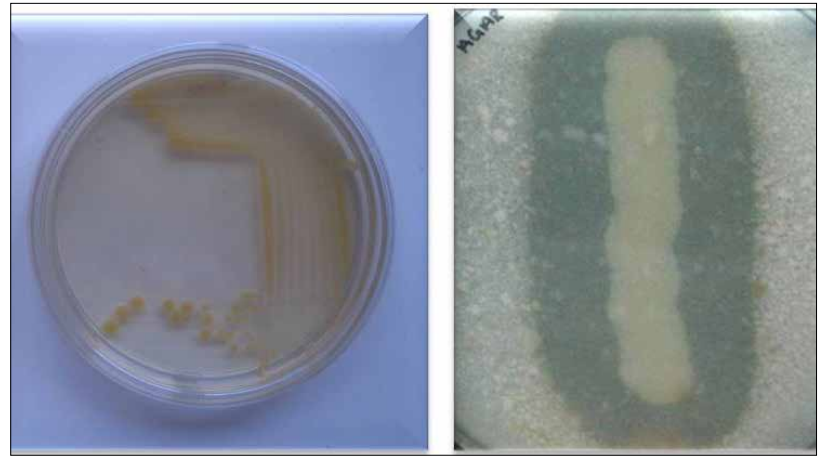

Fig.1. Yellow pigmented and Protease activity of Microbacterium sp.
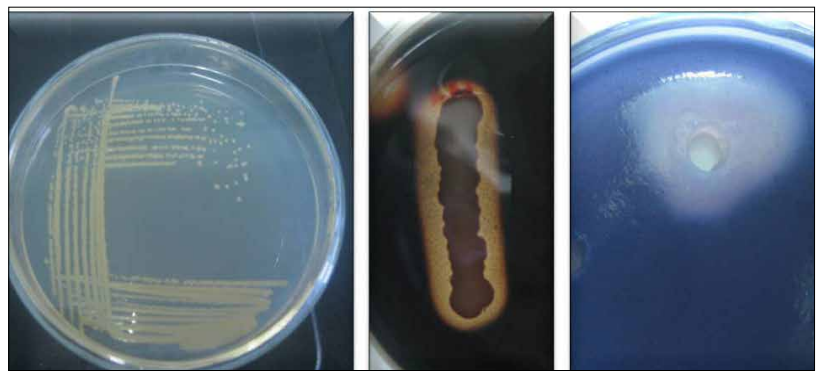

Fig. 2. Yellow pigmented, starch and cellulase activity of Dermacoccus sp.

C. feriata. The strains were belonging to the genera Pseudomonas, Bacillus, Microbacterium and Dermacoccus. Among these Microbacterium sp. was yellow pigmented and with protease activity and Dermacoccus sp. was yellow pigmented, starch utilizing and with cellulolytic activity (Fig. $1 \& 2$ ). These two strains were further characterized by following $16 \mathrm{~S}$ rRNA gene sequence analysis.

\section{Strains identified by 16SrRNA gene sequence analysis}

Genomic extraction of Microbacterium sp. and Dermacoccus $\mathrm{sp}$. resulted in bright bands in the very high base pair range of gel electrophoresis. An OD 260:280 ratios between 1.8 to 2.0 was obtained for the extracted genomic DNA samples, thereby indicating that DNA preparation of the bacterial isolates was proper and the DNA samples were pure, free from protein or phenol contamination. Sequence analysis of PCR products revealed that, for the isolates there was $1 \%$ or no difference with the most closely matched sequences in the data bank. The isolates designated as $\mathrm{AN}-07$ and $\mathrm{AN}-08$ were identified as Microbacterium oxydans and Dermacoccus abyssi respectively. The sequences were deposited at Genbank with the Accession numbers KU937308 and KU937309. The phylogenetic tree (Fig. 3) was inferred from Kimura 2-parameter by the neighbour-joining method. The analysis of $16 \mathrm{~S}$ rRNA gene sequence indicated the position of the native identified isolates in the same cluster with respect to their reference group.

\section{AN-07 Microbacterium oxydans}

Colonies on nutrient agar are yellow, round and with entire edge. They are gram-positive rods, motile with no endospores, measure $1-2 \mu \mathrm{m}$ in length. It is catalase-positive and oxidasenegative. It is gelatin, and protease hydrolyses positive with methyl red-negative, no nitrate reduction and no cellulose hydrolysis. Growth occurs at $20-30^{\circ} \mathrm{C}$, with optimum growth at around $30^{\circ} \mathrm{C}$. The DNA G $+\mathrm{C}$ content of the type strain is $70 \mathrm{~mol} \%$. On the basis of $16 \mathrm{~S}$ rRNA gene sequence, isolate AN- 07 was closely related to $M$. oxydans KMDH1 5 with $99.78 \%$ sequence similarity (Fig. 3).

\section{AN-08 Dermacoccus abyssi}

Colonies on nutrient agar are yellow, circular, entire, convex and irregular clusters. Forms $0.8-1.5 \mathrm{~mm}$ in diameter. Cells produce fluorescent pigment on King's B media. It degraded cellulose and starch. Growth occurs at $10-35^{\circ} \mathrm{C}$, with optimum growth around $28^{\circ} \mathrm{C}$. It tolerates up to $10 \% \mathrm{NaCl}$. The DNA G+C

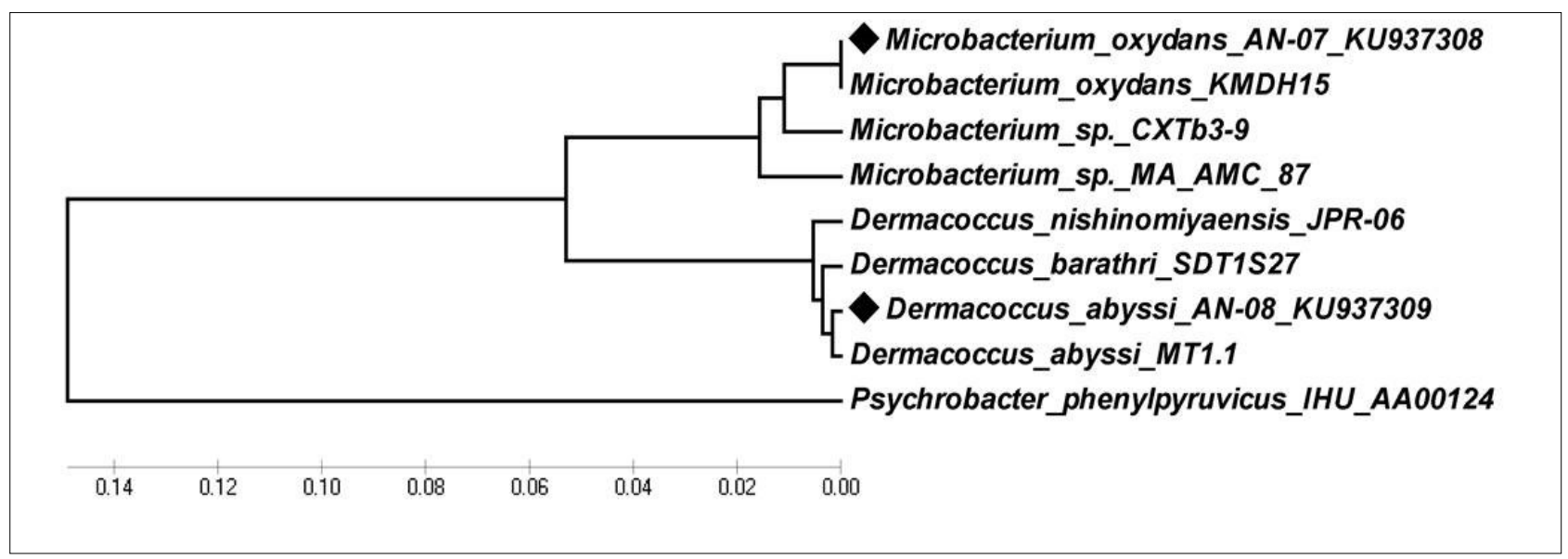

Fig. 3. Phylogenetic relationship of selected bacterial strains based on the neighbour joining method 
content of the type strain is $65.2 \mathrm{~mol} \%$. On the basis of $16 \mathrm{~S}$ rRNA gene sequence, isolate AN- 08 was closely related to $D$. abyssi MT1.1 as reported by Wasu Pathom-aree et al. (2006) with $99.78 \%$ sequence similarity (Fig. 3 ).

\section{Discussion}

The purpose of this study was to isolate and enumerate the bacterial strains in the intestine of $C$. feriata sample from different places along the Kerala coast. Najiah et al. (2010) reported the total bacterial count in S. tranquebarica, S. olivacea and S. serrata as around $10^{4}$ to $10^{6}$. The total bacterial load between $0.7 \pm 0.49 \times 10^{6}$ and $8.9 \pm 0.13 \times 10^{6}$ Cfu. $\mathrm{g}^{-1}$ from intestinal sample of crabs have been reported by Sivasubramanian et al. (2017). In the present study the total culturable bacteria in the intestine of $C$. feriata ranged

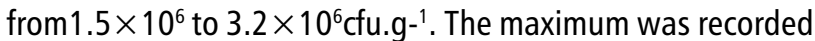
from Kollam, and the minimum from Calicut. Factors, such as bacterial host specificity, food type and water resource may be attributed to explain these differences (Verner-Jeffreys et al., 2003). Bacterial diversity in the surrounding environment and feeding habit of the crab also influence the gastrointestinal bacterial count. Pseudomonas spp. was the predominant genus recorded in the present study. Other isolated genera were Bacillus sp., Microbacterium sp. and Dermacoccus sp. Venkateswaran et al. (1981) have reported that Pseudomonas sp. and Micrococcus sp. were dominant in the intestine of all crabs. In the present study genus Microbacterium sp. and Dermacoccus sp. were scanty, while Pseudomonas spp. was the dominant one. A recent study has found out that settlement by Microbacterium sp. in shrimp hatchery system has considerably improved the larval survival and has been taken into account as a unique probiotic microorganism (Xue et al., 2015). Similarly, for crab the present Microbacterium sp. can be experimented for improved larval survival in hatchery system. The two bacterial strains selected for characterization up to species level were identified as $M$. oxydans and $D$. abyssi. Wasu Pathom-aree et al. (2006) have reported that $D$. abyssi was a piezo-tolerant species isolated from sediments of Mariana Trench in Philippines. D. abyssi MT1.1 had been reported to possess azo-reductase activity and potential for bio-cleaning of industrial dye baths (Weeranuch et al., 2014). M. oxydans has been reported as an alginate and laminarin degrading bacterium for the reutilization of brown-seaweed waste (Eun et al., 2013). They have also found $M$. oxydans capable of reutilization of brown-seaweed waste for the production of reducing sugars. In the present study $M$. oxydans and $D$. abyssi expressed amylolytic, cellulolytic and proteolytic activities. The enzyme activities may be useful in development of probiotics, drugs or in the industrial enzyme production (Gildberg et al., 1997). In commercial aquaculture beneficial bacteria could be introduced by incorporating them into artificial diets and probiotics could improve the digestibility of nutrients, increased tolerance to stress and encourage reproduction. The enzyme producing microorganisms isolated from the intestine of $C$. feriata in the present study may be beneficially used as a probiotic while formulating the diet, especially in the larval stages. However, much more research should be conducted to conclude that addition of such isolates to feeds do in fact, provide some kind of benefit to the animal involved before advocating their use.

\section{Acknowledgements}

The research was carried out under the Application of Microorganisms in Agriculture and Allied Sectors (AMAAS) project of Indian Council of Agriculture Research (ICAR) New Delhi. The authors are grateful to Director CMFRI for the facilities provided to carry out the research.

\section{References}

Bondad Reantaso, M. G., R. P. Subasinghe, H. Josupeit, J. Cai and X. Zhou. 2012. The role of crustacean fisheries and aquaculture in global food security: past, present and future. J. Invertebr. Pathol., 110: 158-165.

Eun Jung Kim., F. Ahmad, J. Gwi-Taek and K. Joong Kyun. 2013. Microbacterium oxydans, a novel alginate- and laminarin-degrading bacterium for the reutilization of brown-seaweed waste. J. Environ. Manage., 130C: 153-159.

Gatesoupe, F. J. 2007. Live yeasts in the gut: natural occurrence, dietary introduction, and their effects on fish health and development. Aquac., 267(1-4): 20-30.

Gildberg, A., H. Mikkelsen, E. Sandaker and E. Ringo. 1997. Probiotic effect of lactic acid bacteria in the feed on growth and survival of Atlantic cod (Gadus morhua). Hydrobiologia, 352: 279-285.

Holt, J. G., R. Noel, Kreg, Sneath, PHA, J. T. Stanley and T. Williams (Eds.). 1994. Bergey's manual of Determinative Bacteriology, Williams \& Wilkins Co., Baltimore, 1(4):787 p.

Kannathasan, A. and K. Rajendran. 2010. Isolation of microbes from various tissues of marine crab Charybdis natator (Herbst, 1789) (Brachyura: Portunidae). Int. J. Recent. Sci. Res., 7: 172-176.

Kasana, R. C., R. Salwan, H. Dhar, S. Dutt and A. Gulati. 2008. A rapid and easy method for the detection of microbial cellulases on agar plates using Gram's iodine. Curr. Microbiol., 57(5): 503-507.

Lane, D. J., B. Pace, G. J. Olsen, D. A. Stahl, M. L. Sogin and N. R. Pace. 1985. Rapid determination of $16 \mathrm{~S}$ ribosomal RNA sequences for phylogenetic analyses. Proc. Natl. Acad. Sci., U S A. 82: 6955-6959.

Li, K., W. Guan, G. Wei, B. Liu, J. Xu, L. Zhao and Y. Zhang. 2007. Phylogenetic analysis of intestinal bacteria in the Chinese mitten crab (Eriocheir sinensis). J. Appl. Microbiol., 103: 675-682

Linnaeus, C. 1758. Systema Naturae per Regna Tria Naturae, Secundum Classes, Ordines, Genera, Species, cum Characteribus, Differentiis Synonymis, Locis. Edition 10. Holmiae., 1: iii + 1-824.

Najiah, M., M. Nadirah, I. Sakri and F. Shaharom-Harrison. 2010. Bacteria Associated with Wild Mud Crab (Scylla serrata) from Setiu Wetland, Malaysia with Emphasis on Antibiotic Resistances. Pak. J. Biol. Sci., 13(6): 293-297.

Oxley, A. P. A., W. Shipton, L. Owensand and D. McKay. 2002. Bacterial flora from the gut of the wild and cultured banana prawn, Penaeus merguiensis. J. Appl. Microbiol., 93:214-223.

Rajendran, K., P. Kavitha, and T. Anbalagan. 2008. Isolation of fungai and bacteria from variation tissues of ice store marine crab Charybdis feriata (Decapoda :Portunidae). J. Aqua. Biol., 23(1):181-184.

Rameshkumar, G., S. Ravichandran, Chandrasekar and T. Ajithkumar. 2009. Gut microbiota of crabs from the Vellar Estuary, southeast coast of India. Microb. Ecol. Health Dis., 21: 178-182.

Ravichandran, S. and T. Kannupandi. 2005. Total heterotrophic bacterial load in decomposing mangrove litter and gut of crabs. Asian J. Microbiol. Biotech. Environ. Sci., 7(4): 861-864.

Reiji, T., O. Masashi, S. Tomoo and T. Kenichi. 2004. Biodiversity and in situ abundance of gut microflora of abalone (Haliotis discus hannai) determined by cultureindependent techniques. Aquac., 241(1-4): 453-463. 
Saha, S., R. N. Roy, S. K. Sen and A. K. Roy. 2006. Characterization of cellulaseproducing bacteria from the digestive tract of tilapia, Oreochromis mossambica (Peters) and grass carp, Ctenopharyngodon idella (Valencinnes). Aquacult. Res., 37: 380-388.

Sambrook, J. and D. W. Russell. 2001. Molecular cloning: a laboratory manual. Cold Spring Harbor Laboratory Press, New York.

Sanchez-Porro, C., S. Martin, E. Mellado and A. Ventosa. 2003. Diversity of moderately halophilic bacteria producing extracellular hydrolytic enzymes. J. Appl. Microbiol., 94(2): 295-300.

Sivasubramanian, K., S. Ravichandran and D. Karthick Rajan. 2017. Isolation of gut associated bacteria from mangrove crabs collected from different mangrove regions of Tamil Nadu, South east coast of India. African J. Microbiol. Res., 11(14): 586-595.

Sugita, H., N. Matsuo, Y. Hirose, M. Iwato and Y. Deguchi. 1997. Vibrio sp. strain NM 10 isolated from the intestine of a Japanese coastal fish has an inhibitory effect against Pasteurella piscicida. Appl. Environ. Microbiol., 63: 4986-4989.

Tamura, K., D. Peterson, N. Peterson, G. Stecher, M. Nei and S. Kumar. 2011. MEGA5: molecular evolutionary genetics analysis using maximum likelihood, evolutionary distance, and maximum parsimony methods. Mol. Biol. Evol., 28(10): 27312739

Varadharajan, D. and P. Soundarapandian. 2014. Proximate composition and mineral contents of freshwater crab Spiralothelphusa hydrodroma (Herbst, 1794) from Parangipettai, south east coast of India. J. Aquacult. Res. Dev., 5: 1-6.
Venkateswaran, K., S. Sethuramalingam and R. Natarajan. 1981. Gut microflora of some edible crabs from Porto Novo coast. Indian J. Mar. Sci., 10: 399-401.

Verner-Jeffreys, D. W., R. J. Shields, I. R. Bricknell and T. H. Birkbeck. 2003. Changes in the gut associated micro-flora during the development of Atlantic halibut (Hippoglossus hippoglossus L.) larvae in three British hatcheries. Aquaculture, 219: 21-42.

Verschuere, L., G. Rombaut, P. Sorgeloos and W. Verstraete. 2000. Probiotic Bacteria as Biological Control Agents in Aquaculture. Microbiol. Mol. Biol. Rev., 64(4): 655671.

Wasu Pathom-aree., N. Yuichi, C. lain, Sutcliffe, C. W. Alan, H. Koki, T. B. Alan and G. Michael. 2006. Dermacoccus abyssi sp. nov., a piezotolerant actinomycete isolated from the Mariana Trench. Int. J. Syst. Evol. Microbiol., 56:1233-7.

Weeranuch, L., S. Sarote, O. M. Ligia and K. Atsuo.2013. Bio-decolorization of a food azo dye by the deep sea Dermacoccus abyssi MT1.1T strain from the Mariana Trench. J. Environ. Manage., 132C:155-164.

Xue, M., H. Liang, Y. He and C. Wen. 2015. Characterization and in-vivo evaluation of potential probiotics of the bacterial flora within the water column of a healthy shrimp larviculture system. Chinese. J. Oceanol. Limnol., 34(3): 484: 491.

Yeon, S. H., W. J. Jeong and J. S. Park. 2005. The diversity of culturable organotrophic bacteria from local solar salterns. J. Microbiol., 43(1):1-10. 